\title{
Compatibility of Interspecific Hybridization in Zantedeschia
}

\author{
Takashi Kubo ${ }^{1,3 *}$, Koji Inaba ${ }^{2,3}$ and Genjiro Mori ${ }^{4}$ \\ ${ }^{1}$ Department of Horticulture and Landscape Architecture, Hokkaido Collage, Senshu University, Bibai 079-0197, Japan \\ ${ }^{2}$ Kyoto Prefectural Institute of Agriculture, Wakunari, Amarube-cho, Kameoka 621-0806, Japan \\ ${ }^{3}$ Kyoto Prefectural Institute of Agricultural Biotechnology, Oji, Kitainayazuma, Seika-cho, Soraku 619-0244, Japan \\ ${ }^{4}$ Graduate School of Life and Environmental Sciences, Osaka Prefecture University, Gakuen-Cho, Saka 599-8531, Japan
}

Two cultivars of Zantedeschia aethiopica (group 1) and 21 cultivars in other Zantedeschia spp. (group 2) were hybridized to investigate the cross-compatibility of each combination. From a total of 757 crosses from 37 hybrid combinations that were attempted, 3,144 resulting embryos were cultured. As a result, 175 embryos representing 26 combinations formed shoots, but all hybrids were albino and viable only in vitro. Some hybrids had plastids of both parents, but no relationship between the appearance of albino hybrids and plastid inheritance could be detected.

Key Words: embryo culture, interspecific hybrid, Zantedeschia.

\section{Introduction}

The genus Zantedeschia, which contains six species and two sub-species, is divided into two groups (Funnell, 1993). The group 1 contains only $Z$. aethiopica, an evergreen spp. in which the inflorescence appears in late winter to late spring in its native habitat. Group 2 contains the remaining five species, which are deciduous and flower in summer.

The species, belonging to group 2 , have various spathe colors, whereas $Z$. aethiopica has only white, pink, or green spathes with a long flowering period. Hybrids with characters from both groups are therefore very attractive for plant breeders. Interspecific hybrids are readily achieved between species within group 2; however, because of postfertilization barriers, no successful crosses have been achieved between species in groups 1 and 2 (Traub, 1948). Yao et al. (1995) obtained fertilized embryos of these incompatible crosses by using an embryo-rescue technique, but all hybrids were albino and viable only in vitro.

Yao et al. (1995) obtained albino hybrids by using only 4 cross-combinations. The hybrids, viable autotrophically, may be obtained from the crosses of more combination patterns. In this study, we performed crosses between 2 cultivars of Z. aethiopica and 21 cultivars in group 2 to obtain hybrids from more combination patterns and investigated their compatibility. Incompatibility between the genome and plastome could be one of the factors to cause this dysfunction (Michishita et al., 2002). Hence, the relationship between

Received; May 23, 2005. Accepted; October 12, 2005.

A part of this study was presented at 2005 Spring Meeting of the Japan. Soc. Hort. Sci.

* Corresponding author (E-mail: kubo@senshu-hc.ac.jp). the appearance of albino hybrids and plastid inheritance were also investigated.

\section{Materials and Methods}

Investigation of the compatibility of interspecific hybridization

Crosses were performed between 2 cultivars of $Z$. aethiopica and 21 cultivars in group 2. Plants were grown in greenhouses to achieve simultaneous flowering. The maternal plants were emasculated and fresh pollen applied to the stigma. After pollination, inflorescences were covered with waxed paper bag to prevent contamination.

The ovaries that were harvested 6 to 8 weeks after pollination were surface-sterilized with sodium hypochlorite solution (active chloride: about $2 \%$ ) for $15 \mathrm{~min}$ and rinsed thrice with sterilized water. The embryos were cultured in Murashige and Skoog (1962) (MS) medium that contained $2 \mathrm{~g} \cdot \mathrm{L}^{-1}$ gelrite, $30 \mathrm{~g} \cdot \mathrm{L}^{-1}$ sucrose, $1 \mathrm{mg} \cdot \mathrm{L}^{-1} \mathrm{BA}$, and $0.1 \mathrm{mg} \cdot \mathrm{L}^{-1} \mathrm{NAA}$. The fertilized embryos were separated from the endosperms and cultured on the media at $25^{\circ} \mathrm{C}$ in the dark. Embryos that were too small to be separated from the endosperm were cultured together. When the embryos had grown more than $5 \mathrm{~mm}$, they were transferred to a 16-h photoperiod illuminated by cool white fluorescent light $\left(40 \mu \mathrm{mol} \cdot \mathrm{m}^{-2}\right.$. $\mathrm{s}^{-1}$ ) and kept at $25^{\circ} \mathrm{C}$. The embryos that formed shoots were transferred to $1 / 2 \mathrm{MS}$ medium to induce rooting.

\section{Investigation of plastid inheritance}

The sizes of PCR products amplified from DNA of the progeny by using a primer pair specific to atp $\mathrm{H}$ (atpH-1 and atpH-2) of the plastid DNA were investigated to identify which parent's plastid was inherited. atpH-1 (5'-TTGACCAACTCCAGGTCCAA3') and atpH-2 (5'-CCGCAGCTTATATAGGCGAA) 
designed from plastid DNA of Spinacia oleraces (Tsumura et al., 1996) amplify about 600- and 900-bp fragments in $Z$. aethiopica and cultivars in group 2, respectively. $20 \mathrm{ng}$ of total DNA that was extracted from leaf tissues by a modified CTAB method (Rogers and Bendich, 1985) was added to a reaction mixture $(10 \mu \mathrm{L})$ containing $1 \mathrm{mM}$ of each primer, $0.2 \mathrm{mM}$ of each dNTP, 0.25 units of Taq (TAKARA Co., Kyoto, Japan), and $1 \mu \mathrm{L}$ of $\times 10$ buffer for Taq. Amplification was carried out in a thermal cycler (Applied Biosystem 9600, Applied Biosystem, California, USA) for $5 \mathrm{~min}$ at $94^{\circ} \mathrm{C}$ followed by 40 cycles of $1 \mathrm{~min}$ at $94^{\circ} \mathrm{C}, 2 \mathrm{~min}$ at $60^{\circ} \mathrm{C}$ and $2 \mathrm{~min}$ at $72^{\circ} \mathrm{C}$, and ending with $7 \mathrm{~min}$ incubation at $72^{\circ} \mathrm{C}$.

\section{Results}

Investigation of the compatibility of interspecific hybridization

A total of 757 crosses from 37 cross-combinations were attempted from which 3,144 embryos were cultured (Table 1). Overall, 175 embryos formed shoots from crosses of 26 combination patterns, and the percentages of embryos that formed shoots were $1.1-20.0 \%$. But, these shoots were barely pigmented even under illumination; the SPAD value of these leaves was less than 2.0. Furthermore, these albino shoots grew very slowly and barely rooted. Several plantlets rooted and grew over $5 \mathrm{~cm}$; these were transplanted into soil mixture, and then placed in a greenhouse controlled at $25^{\circ} \mathrm{C}$. These hybrids survived for about one month, but remained albino and never unfolded new leaves. All albino hybrids were identified as interspecific hybrids by RAPD analysis (data not shown).

\section{Investigation of plastid inheritance}

By investigating six albino hybrids derived from 'Wedding March' $\times$ 'Black Eyed Beauty', and 'Wedding March' $\times$ 'Pink Superba', biparental inheritance of plastid DNA was detected in 3 hybrids derived from 'Wedding March' × 'Black Eyed Beauty' and one from 'Wedding March' × 'Pink Superba' (Fig. 1).

\section{Discussion}

Yao et al. (1995) previously obtained interspecific hybrids from 4 combination patterns, $Z$. aethiopica $\times Z$. elliottiana and 3 hybrid cultivars of group $2 \times Z$. aethiopica. In this study, hybrids from 2 cultivars of $Z$. aethiopica $\times Z$. rehmanii 'Pink Superba' were obtained, but these were albino and viable only in vitro, as with those of $Z$. aethiopica $\times Z$. elliottiana obtained by Yao et al. (1995). Furthermore, though we also obtained hybrids from crosses using even 21 hybrid cultivars of group 2 as paternal or maternal parent, all progenies were albino. These results imply that there is a genetic

Table 1. The results from interspecific hybridization in Zantedeschia.

\begin{tabular}{|c|c|c|c|c|c|c|}
\hline \multicolumn{2}{|c|}{ Parents } & \multirow{2}{*}{$\begin{array}{c}\text { Number of crosses } \\
\text { attempted }\end{array}$} & \multirow{2}{*}{$\begin{array}{c}\text { Number of embryos } \\
\text { cultured }\end{array}$} & \multirow{2}{*}{$\begin{array}{l}\text { Number of embyos } \\
\text { forming shoot }\end{array}$} & \multirow{2}{*}{$\begin{array}{l}\text { Percentage of embyos } \\
\text { forming shoot }(\%)\end{array}$} & \multirow{2}{*}{$\begin{array}{l}\text { Hybrid shoot } \\
\text { colour }\end{array}$} \\
\hline Maternal & Paternal & & & & & \\
\hline \multirow[t]{19}{*}{ 'Wedding March' } & 'Black Eyed Beauty' & 68 & 664 & 43 & 6.5 & albino \\
\hline & 'Pink Superba' & 99 & 552 & 40 & 7.2 & albino \\
\hline & 'Chianti' & 26 & 111 & 13 & 11.7 & albino \\
\hline & 'Golden Giant' & 29 & 131 & 9 & 6.9 & albino \\
\hline & 'Black Magic' & 36 & 449 & 7 & 1.6 & albino \\
\hline & 'Parfait' & 18 & 98 & 5 & 5.1 & albino \\
\hline & 'Sunshine' & 43 & 113 & 5 & 4.4 & albino \\
\hline & 'Soft Glow' & 19 & 62 & 4 & 6.5 & albino \\
\hline & 'Carmine Red' & 18 & 15 & 3 & 20.0 & albino \\
\hline & 'Majestic Red' & 13 & 78 & 2 & 2.6 & albino \\
\hline & 'Florex Gold' & 11 & 11 & 2 & 18.2 & albino \\
\hline & 'Neone Amour' & 31 & 28 & 2 & 7.1 & albino \\
\hline & 'Deep Rose Gem' & 34 & 93 & 1 & 1.1 & albino \\
\hline & 'Millennium Gold' & 11 & 22 & 0 & 0.0 & - \\
\hline & 'Hazel Mary' & 4 & 10 & 0 & 0.0 & - \\
\hline & 'Mango' & 13 & 6 & 0 & 0.0 & - \\
\hline & 'Crystal Glow' & 19 & 10 & 0 & 0.0 & - \\
\hline & 'Crystal Brash' & 17 & 8 & 0 & 0.0 & - \\
\hline & 'Lip Stick' & 22 & 8 & 0 & 0.0 & - \\
\hline \multirow[t]{13}{*}{ 'Childsiana' } & 'Pink Superba' & 47 & 109 & 6 & 5.5 & albino \\
\hline & 'Black Eyed Beauty' & 49 & 139 & 3 & 2.2 & albino \\
\hline & 'Chianti' & 11 & 43 & 3 & 7.0 & albino \\
\hline & 'Parfait' & 6 & 37 & 2 & 5.4 & albino \\
\hline & 'Golden Giant' & 24 & 16 & 1 & 6.3 & albino \\
\hline & 'Lip Stick' & 4 & 28 & 1 & 3.6 & albino \\
\hline & 'Soft Glow' & 11 & 8 & 1 & 12.5 & albino \\
\hline & 'Majestic Red' & 7 & 8 & 1 & 12.5 & albino \\
\hline & 'Black Magic' & 22 & 46 & 0 & 0.0 & - \\
\hline & 'Super Gem' & 2 & 1 & 0 & 0.0 & - \\
\hline & 'Crystal Glow' & 5 & 9 & 0 & 0.0 & - \\
\hline & 'Deep Rose Gem' & 3 & 7 & 0 & 0.0 & - \\
\hline & 'Carmine Red' & 3 & 4 & 0 & 0.0 & - \\
\hline 'Black Eyed Beauty' & 'Wedding March' & 2 & 15 & 2 & 13.3 & albino \\
\hline 'Black Eyed Beauty' & 'Childsiana' & 15 & 121 & 8 & 6.6 & albino \\
\hline 'Black Magic' & & 6 & 31 & 5 & 16.1 & albino \\
\hline 'Best Gold' & & 5 & 31 & 5 & 16.1 & albino \\
\hline 'Mango' & & 4 & 22 & 1 & 4.5 & albino \\
\hline \multicolumn{2}{|c|}{ Total } & 757 & 3144 & 175 & 5.7 & \\
\hline
\end{tabular}




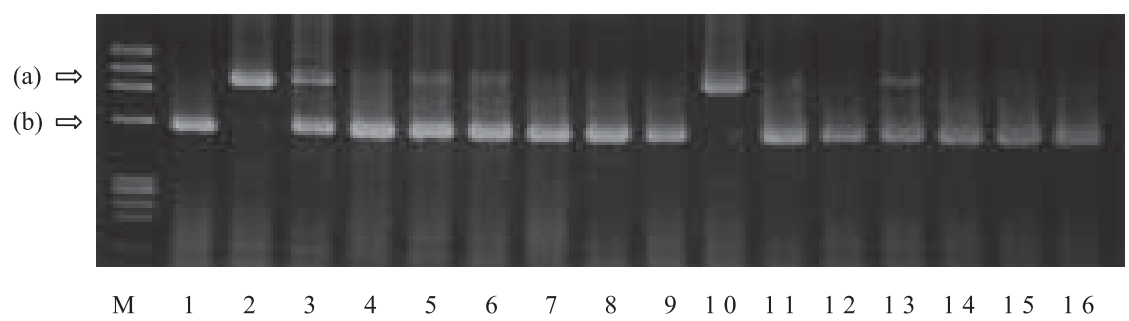

Fig. 1. Gel plates showing the PCR products amplified using a primer pair specific to atpH. Lane M, Size marker derived from $\phi X 174 / H a e I I I ;$ Lanes 1 and 9, Z. aethiopica 'Wedding March'; Lane 2, Z. hybrida 'Black Eyed Beauty'; Lanes 3-8, albino hybrids derived from 'Wedding March' × 'Black Eyed Beauty'; Lane 10, Z. hybrida 'Pink Superba'; Lanes 11-16, albino hybrids derived from 'Wedding March' $\times$ 'Pink Superba'. Fragments (a) and (b) are specific to plastids of species in group 2 and Z. aethiopica, respectively.

barrier between Z. aethiopica and species of group 2 . Inoue (1996) reported that the hybrid lethality in interspecific hybrid between Nicotiana gossei and $N$. tabacum was avoided by irradiating pollen with ion beams which induced gene deletion. Attempts could be made to remove the factors causing postfertilization barriers by inducing mutation on pollen or albino hybrids.

The dysfunctions of chlorophyll synthesis were observed in interspecific hybrids of Impatiens (Arisumi, 1985) and Rhododendron (Ureshino and Miyajima, 2002). Incompatibility between the genome and plastome could be one of the factors causing this dysfunction (Michishita et al., 2002). It was previously shown that, in Zantedeschia, plastids could be inherited from both parents (Yao et al., 1994). Snijder (2004) showed that diminution of chlorophylls in hybrids, derived from interspecific crosses among group 2 Zantedeschia species, was caused by incompatibility between the genome and plastome. Biparental inheritance of plastids was also detected in some hybrids obtained in this study (Fig. 1). But, no relationship between the appearance of albino hybrids and plastid inheritance was detected, which implies that a hybrid genome was incompatible to both parental plastids, or that the dysfunction of chlorophyll synthesis was caused by other factors, such as the hybrid genome in itself or incompatibility between genome and mitochondrial genome.

In this study, no compatible combinations were detected, because all hybrids were albino that survived only in vitro. Further studies are required to elucidate the causes for the appearance of albino hybrids.

\section{Literature Cited}

Arisumi, T. 1985. Rescuing abortive Impatiens hybrids through aseptic culture of ovules. J. Amer. Soc. Hort. Sci. 110: 273-276.

Funnell, K. A. 1993. Zantedeschia. p. 683-704. In: A. De Hortogh and M. Le Nard (eds.). The physiology of flower bulbs. Elsevier, Amsterdam-London-New York-Tokyo.

Inoue, M. 1996. Irradiating pollen with ion beams for plant breeding. Nuclear Engineering, 42(12): 57-61 (In Japanese).

Michishita, A., K. Ureshino and I. Miyajima. 2002. Plastomegenome incompatibility of Rhododendron serpyllifolium
(A. Gray) Miq. to evergreen azalea species belonging to series Kaempferia. J. Japan. Soc. Hort. Sci. 71: 375-381.

Murashige, T. and F. Skoog. 1962. A revised medium for rapid growth and bioassays with tobacco tissue cultures. Physiol. Plant. 15: 473-497.

Rogers, S. O. and A. J. Bendich. 1985. Extraction of DNA from milligram amounts of fresh, herbarium and mummified plant tissues. Plant Mol. Biol. 5: 69-76.

Snijder, R. C. 2004. Genetics of Erwinia resistance in Zantedeschia: impact of plastome-genome incompatibility. Ph. D. Thesis. Wageningen Univ., Wageningen.

Traub, H. P. 1948. The genus Zantedeschia. Plant Life 4: 9-32.

Tsumura, Y., T. Kawahara, R. Wickneswari and K. Yoshimura. 1996. Molecular phylogeny of Dipterocarpaceae in Southeast Asia using RFLP of PCR amplified chloroplast genes. Theor. Appl. Genet. 93: 22-29.

Ureshino, K. and I. Miyajima. 2002. The study on the relationship between leaf colors and ptDNA inheritance in intersectional cross of Rhododendron kiusianum $\times R$. japonicum f. flavum, resulting in an unexpected triploid progeny. J. Japan. Soc. Hort. Sci. 71: 214-219.

Yao, J. L., D. Cohen and R. E. Rowland. 1994. Plastid DNA inheritance and plastome-genome incompatibility in interspecific hybrids of Zantedeschia (Araceae). Theor. Appl. Genet. 88: 255-260.

Yao, J. L., D. Cohen and R. E. Rowland. 1995. Interspecific albino and variegated hybrids in the genus Zantedeschia. Plant Sci. 109: 199-206.

\section{カラー種間交雑における交雑和合性の調査 \\ 久保 崇 ${ }^{1,3 *} \cdot$ 稲葉幸司 ${ }^{2,3} \cdot$ 森 源治郎 ${ }^{4}$}

1専修大学北海道短期大学 079-0197 美唄市字美唄

2京都府農業総合研究所 621-0806 亀岡市余部町

3京都府農業資源研究センター

619-0244 京都府相楽郡精華町

${ }^{4}$ 大阪府立大学大学院 生命環境科学研究科 599-8531 堺市学園町

Zantedeschia aethiopica (グループ 1) およびグループ 1 以外の Zantedeschia 属 5 種（グループ 2）に属する種 間に打ける交雑和合性について調査寸るため,グループ 1 を2 品種, グループ 2 を 21 品種用いて交雑を行った. 37 組久合わせの交雑より得られた 3144 個の雑種肧を培 養し，26 の交雑組久合わせから 175 個の雑種個体を得 た. しかし，得られた全ての雑種個体はアルビノ個体で あり，独立栄養環境下での生育は不可能であった。な抏， いくつかの雑種個体でプラスチドの両性遺伝が認められ たが，このことと雑種個体の色との関係は見出せなかった。 